\title{
Seasonal Variation of Sargassum Muticum Biochemical Composition Determined by Fourier Transform Infra-Red Spectroscopy
}

\author{
Deniel Maureen ${ }^{1,2}$, Puspita Maya ${ }^{2,3}$, Douzenel Philippe ${ }^{2}$, Stiger-Pouvreau Valérie ${ }^{4}$, Bedoux Gilles ${ }^{2}$, \\ Bourgougnon Nathalie ${ }^{2}$,Vandanjon Laurent ${ }^{1,2^{*}}$
}

${ }^{1}$ Université de Nantes, GEPEA-UMR CNRS 6144, F-44600 Saint-Nazaire, France

${ }^{2}$ Université Bretagne Sud, EA 3884, LBCM, IUEM, F-56000 Vannes, France

${ }^{3}$ Diponegoro University, Faculty of Fisheries and Marine Science, Marine Science Department, Semarang, 50275 Indonesia

${ }^{4}$ Université de Bretagne Occidentale, LEMAR-UMR CNRS IRD IFREMER 6539, F-29280 Plouzané, France

*Corresponding author: Vandanjon Laurent, Université de Nantes, GEPEA-UMR CNRS 6144, F-44600 Saint-Nazaire, France, Université Bretagne Sud, EA 3884, LBCM, IUEM, F-56000 Vannes, France, Tel: +33 297017125;

Email: laurent.vandanjon@univ-ubs.fr

\begin{abstract}
Proliferation of the introduced brown macro alga Sargassum muticum is known as a natural and hard to control phenomenon occurring along the Atlantic coasts. The phenomenon causes serious troubles for local ecosystems including the alteration of ecosystem structure, the reduction in indigenous biodiversity and economic losses (tourism, aquaculture). However, despite the serious troubles caused by S. muticum, this species contains highly remarkable bioactive metabolites. This macro alga is at present under-exploited and the valorization of its metabolites to give a positive value to this seaweed could be a solution of ecosystemic service. Biorefinery process could be one solution to valorize $S$. muticum. Comprehensive knowledge concerning the biochemical composition of $S$. muticum and the impact of environmental factors, particularly seasons, on its composition is a prerequisite before its valorization. In this study, the biochemical composition of $S$. muticum was evaluated by using classic colorimetric methods based on chemical analysis and Fourier Transform Infra-Red spectrometry (FTIR), and was used as a rapid and safe method that could bring advantages in screening studies and a more comprehensive management and use of seaweed products. Our results are globally in accordance, notably for phenolic compounds, showing the relevance of the use of infrared spectrometry. Moreover, based on the absorption bands of some specific and valuable compounds shown by FTIR, there was a seasonal variation in the polysaccharides, i.e., uronic acids and sulphated compounds, together with phenolic contents of $S$. muticum.
\end{abstract}

Keywords: FTIR spectroscopy; Colorimetric method; Biochemical composition; Seasonal variation, Sargassum muticum
Received Date: May 26, 2017

Accepted Date: September 21, 2017

Published Date: September 27, 2017

Citation: Vandanjon Laurent., et al. Seasonal Variation of Sargassum Muticum Biochemical Composition Determined by Fourier Transform Infra-Red Spectroscopy. (2017) J Anal Bioanal Sep Tech 2(1): $75-84$.

DOI: $10.15436 / 2476-1869.17 .1555$

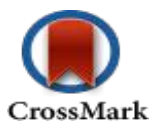

\section{Introduction}

Macro algae in Brittany are very diverse with more than 800 species reported in coastal areas ${ }^{[1]}$. Among this flora, native or introduced macro algae can become proliferative. The brown macro alga Sargassum muticum (Fucales), native from Japan spreads along Atlantic coasts, from the southern Portugal to the northern coast of Norway. Introduction of this alga in Europe matches with the beginning of the importation of oysters Crassostrea gigas. Proliferations of S. muticum and large piles of decomposing biomass appear along the north shallow sandy bays, causing an economic constraint for the affected communities. Such phenomenon defi- 
nitely becomes a serious problem for local ecosystems including the alteration of ecosystem structure, reduction in indigenous biodiversity, azoic habitat (excessive oxygen consumption), economic losses mainly for important industries such as tourism $^{[2]}$.

Brown algae are composed of proteins, uronic acids, polysaccharides, mineral matter and phenolic compounds. Other compounds are important such as mannitol or laminarin,storage $\beta$-glucan, and pigments like fucoxanthin, chlorophylls a and c.

Proteins contained in algae are interesting particularly from a nutritional point of view. To face the increasing demand for food, new sources of proteins must be discovered ${ }^{[3]}$. The genus of Sargassum can supply essential amino acids such as threonine, alanine, valine, lysine and proline. According to Holdt \& Kraan (2011), glutamic and aspartic acid represent around $40 \%$ of the total amino acids of S. muticum and they may be used in the frame of protein supplementation in human nutrition.

S. muticum contains around $30 \%$ of mineral matter ${ }^{[4]}$. It is a high value compared to terrestrial plants but not the maximum value observed in brown algae. Indeed, Sacchoriza polyschides consists of $55.4 \%$ of mineral matter ${ }^{[5]}$. The presence of trace minerals $(\mathrm{Zn}, \mathrm{Mn}, \mathrm{Cu}, \mathrm{Fe})$ in this matrix makes $S$. muticum interesting for an utilization as a feed complement or as a fertilizer in agriculture ${ }^{[6]}$.

Matricial polysaccharides are present in the algal cell wall. Two forms coexist in Phaeophyceae: alginates and fucoidans. Alginates (or alginic acids) are constituted by linear polymers with $\beta$-L-guluronic acid units (GG unit), $\alpha$-D-mannuronic acid units (MM unit) and also mixed units (MG unit) associated by 1-4 linkage ${ }^{[7]}$. Fucoidans are polymers mainly constituted by sulfated fucose with L conformation or other sulfated monosaccharides ${ }^{[8]}$. Fucoidans obtained from brown algae have antivi$\mathrm{ral}^{[9]}$, antioxidant ${ }^{[10]}$, antiproliferant /antitumoral ${ }^{[11,12]}$, anticoagulant $^{[13]}$ as main activities.

Brown macro algae, in particular S. muticum, produce phenolic compounds called phlorotannins (phloroglucinol-like molecules), which have a molecular weight between $126 \mathrm{Da}$ and $650 \mathrm{kDa}^{[14]}$. These compounds are well known for their bioactivities such as antioxidant, antitumoral, antibacterial or photoprotectant ${ }^{[15-17]}$. It has been observed that phenolic contents fluctuate all along the year with values comprised between 1 and $6 \%$ of dry weight ${ }^{177-19]}$.

Previous studies showed that the biochemical composition of S. muticum can vary depending on geographic localiza$\operatorname{tion}^{[20]}$. These results emphasize the importance of comprehensive insights regarding the biochemical composition variation of S. muticum for further upgrading of this alga for food industry in Europe. Basic information related to the biochemical composition and impact of season towards the biochemical composition of S. muticum is essential prior to further exploitation. This information sets a reference to know when the most convenient harvest period will be possible, basing the choice on the biochemical composition of the macro alga. Furthermore, seasonal harvesting is as an alternative to control the proliferation of $S$. muticum.

S.muticum is used in Asia as a food supplement (Korea) and feed(sea cucumber, abalone) in China ${ }^{[21]}$. Bioactive compounds such as fucoxanthin, sulfated polysaccharides and terpenoids are present in Sargassum species ${ }^{[2]}$. Fucoxanthin, is a pigment which is the subject of many publications for its anti-inflammatory and antioxidant ${ }^{[23]}$ properties. $S$. muticum is considered as a renewable source of interesting bioactive phenolic compounds ${ }^{[19]}$. With interest in new renewable sources of chemicals and polymers, this underexploited biomass represents a potential source to investigate. S. muticum is yet more rarely used in European countries than in Asian countries. Most of the generated biomass is today of little value with the exception of its use as compost, or biogas from stranding events in over-seas French Departments, Guadeloupe and Martinique ${ }^{[2]}$.

In the same time, the bioprocess industries have made progress and so new perspectives for the conversion of the whole macro algae through the production of new compounds are considered. Nowadays, industrial seaweed exploitation is usually single-product oriented and the active components have not been fully characterized. This is partly due to the complexity of the biological and chemical levels of the raw material, together with the technical level of the extraction processes. The main challenges of the successful development of such a biorefinery approach will be in:

i. Reducing the environmental impact of the process since the co-production of economically valuable components (e.g., pigments, proteins, peptides, and poly- or oligosaccharides) will be associated with the minimization of waste products. Recently, several patents on upgrading strategies of S. muticum and environmental impact were developed by Pérez-Lopéz et a ${ }^{[24]}$.

ii. Delivering a robust scientific and technological basis for orientating strategic decisions over the industrial development of high added-value algal products.

Our study was then dedicated to the monitoring of the biochemical composition of the proliferative brown macro alga S. muticum along a one year cycle in Brittany (France). Several parameters were monthly measured by conventional chemical methods: dry matter, ash and organic matter content, neutral sugars, cell wall polysaccharides, uronic acids, sulphates, phenolic compounds, and proteins, in order to identify the primary metabolites entering in the composition of the biomass. In parallel, a new, rapid and non-destructive experimental method such as Fourier Transform Infra-Red spectrometry (FTIR) could bring advantages in screening studies and then a more comprehensive management and use of seaweed products. In this study, FTIR with Attenuated Transmission Reflectance (ATR) module has been used. It is a middle Infra-Red technique which allows resonance detections of fundamental bonds between atoms. This spectrometric method provides information on the biochemical composition of seasonal samples of S. muticum. The main advantage of this technique compared to conventional methods (biochemical assays) is its rapidity in the acquisition of spectra, permitting a chemical fingerprinting of samples and then a view of macromolecules contents. It permitted then considerable time saving in terms of experimentation ${ }^{[20,25,26]}$. In a very short time, absorbance spectra with high resolution and good reproducibility are obtained. Moreover, no solvent or chemical products are used which are often toxic for the environment.

Infra-Red spectrometry is used for three main applications: identification, quality control and structural elucidation. Infra-Red spectroscopy has already been used on algae to analyze nutrients, to identify polysaccharides structures or fucoidans ${ }^{[27]}$ and also to get a physiological fingerprint of the potential growth of microalgae. Ecotoxicological studies can also benefit from this technique, which allows the observation of metal 
biosorption by algae ${ }^{[28]}$. Considerable technological advances on this process now allow the use of FTIR as a quantification tool for evaluating macromolecules composition changes in microal$\mathrm{gae}^{[29]}$. This quantification is possible under specific conditions, by means of linear regression and standardizations.

In light of this context, it is clear that an improved knowledge of the biochemical composition of S. muticum has a great interest. The aim of this study was then to analyze the seasonal variations of $S$. muticum biochemical composition collected in South Brittany (France) by combining colorimetric and FTIR analyses. The final objective of our work is to propose a spectrometric tool to industrials and researchers as a simple method to characterize natural resources biomass in term of biochemical composition for any monitoring carried out in relation with space and time (spatio-seasonal variations of compounds).

\section{Material and Methods}

\section{Algal Material}

Sargassum muticum (Yendo) Fensholt was monthly collected at Piriac-sur-Mer (France) $\left(47^{\circ} 22^{\prime} 38.0^{\prime \prime} \mathrm{N}, 2^{\circ} 33^{\prime} 20.4^{\prime \prime} \mathrm{W}\right)$ from July 2014 to June 2015.

Thalli fixed on shore were harvested by cutting them with scissor $5 \mathrm{~cm}$ from the holdfast to allow the thalli regeneration. Collected thalli of S. muticum were washed with freshwater to eliminate salts and epiphytes. Then, they were stored at $-80^{\circ} \mathrm{C}$ before freeze-drying and milled to $3.0 \mathrm{~mm}$ particle size. The freeze-dried algae were stored in plastic bags away from direct contact to light.

Meteorological data, i.e. precipitations, sunlight, temperature (air, seawater, minimum, maximum), used in this study were obtained from http://www.meteociel.fr/climatologie/. The station studied was Saint-Nazaire, the closest station to Piriac.

Thalli of S. muticum are diploid and the species presents a monogenetic life cycle ${ }^{[30]}$. In Europe, during October and November, young blades appear on basal holdfast corresponding to the beginning of growth. S. muticum continues its development all along the winter to reach its maximal size in spring. Growth is then reduced and stopped when reproduction takes place in April/May in Brittany ${ }^{[18]}$. In August and September, aerocysts from laterals begin to fall leading to a decrease in floatability and the shoots develop on the bottom, corresponding to the degeneration period. The laterals deteriorate, whereas the basal holdfast remains and persists. S. muticum is then a pseudo-perennial spe$\operatorname{cies}^{[30]}$.

\section{FTIR-ATR analysis}

Freeze-dried algae were analyzed by Fourier Transform Infrared Spectroscopy with attenuated total reflectance. The FTIR spectra were recorded on a Nicolet iS5 FTIR spectrometer (Thermo Scientific) using an iD7 ATR module with a diamond crystal. All spectra resulted from 32 scans and a resolution of $1.928 \mathrm{~cm}^{-1}$ from 500 to $4000 \mathrm{~cm}^{-1}$. The OMNIC software was used for data acquisition (absorbance mode). A background reference was obtained before each sample measurement. All samples were recorded in triplicates. The spectra were studied between 600 and $1800 \mathrm{~cm}^{-1}$ zone, to avoid absorbance of water zone $\left(3600-3100 \mathrm{~cm}^{-1}\right)$.

\section{Acid and aqueous hydrolysis of $S$. muticum}

Freeze-dried algae $(10 \mathrm{mg})$ were mixed in vials with 5 $\mathrm{mL}$ of MilliQ water or $\mathrm{HCl} 1 \mathrm{M}$ respectively for water extraction (sulphates, phenolic compounds) and acid hydrolysis (proteins, neutral sugars, uronic acids). The vials, airtight closed, were stored at $100^{\circ} \mathrm{C}$ for 2 hours. Stirring was carried out every 30 $\min$. At the end of the incubation, hydrolysis was stopped by ice cooling and then $5 \mathrm{~mL}$ of water (aqueous hydrolysis) or $\mathrm{NaOH}$ $1 \mathrm{M}$ (acid hydrolysis) were added. Furthermore, samples were stored at $+4^{\circ} \mathrm{C}$ (one week) or at $-20^{\circ} \mathrm{C}$. The hydrolyzed extracts were used for the composition study by biochemical assays. Samples were prepared in triplicate.

\section{Biochemical analysis \\ Dry matter and mineral content}

The dry matter was obtained from $2 \mathrm{~g}$ of fresh algae put in an oven for $24 \mathrm{~h}$ at $100^{\circ} \mathrm{C}$ and then in a desiccators $(20 \mathrm{~min})$. Results were expressed in \% of dry matter of fresh algae.

Mineral matter content was determined by incubating freeze-dried algae $(100 \mathrm{mg})$ at $100^{\circ} \mathrm{C}$ in an oven $(40 \mathrm{~min})$ to eliminate traces of water. The organic matter in algal material was obtained after burning with a Bunsen burner $(5 \mathrm{~min})$ and directly put at $585^{\circ} \mathrm{C}$ for calcinations $(2 \mathrm{~h}, \mathrm{CSF} 1100$, Carbolite Furnaces). Results were expressed in $\%$ of mineral matter of dried algae.

\section{Neutral sugars}

Neutral sugars content was evaluated by the colorimetric method with phenol sulfuric acid. Analyses were performed in triplicate. Glucose prepared in different concentrations $(0-$ $100 \mu \mathrm{g} . \mathrm{mL}^{-1}$ ) served as a standard curve. The absorbance was measured at $490 \mathrm{~nm}$ (Spectro UV-1800, Shimadzu).

\section{Proteins contents}

The protein content of hydrolyzed algae was determined by the reduction of ions $\mathrm{Cu}^{2+}$ into $\mathrm{Cu}^{+}$by proteins in alkaline medium using the bicinchoninic acid colorimetric method $(\mathrm{BCA})^{[31]}$. A calibration curve was prepared with a Micro BC Assay Kit (ref. 23227, Thermo Scientific) between 0 and 500 $\mu \mathrm{g} . \mathrm{mL}^{-1}$ of BSA (bovine serum albumin). For comparison with the protein assay, the total nitrogen content $(\% \mathrm{~N})$ was determined using the Kjeldahl method ${ }^{[32]}$.

\section{Uronic acids contents}

This method was developed from Blumenkrantz \& Asboe-Hansen (1973) and modified by Pierre (2010) ${ }^{[33]}$. The absorbance was read at $525 \mathrm{~nm}$ (Spectro UV-1800, Shimadzu).

\section{Sulphate groups content}

The sulphate groups content was determined according to the Azure A modified colorimetric method. The Azure A (Sigma-Aldrich A6270) reacts specifically with sulphates linked to polysaccharides. This reaction is based on the formation of a complex between sulphated groups and the 3-amino-7-(dimethylamino) phenothizin-5-ium (Azure A). A solution of sulphated dextran $(17 \%)$ was used as a standard $\left(0-100 \mu \mathrm{g} \cdot \mathrm{mL}^{-1}\right)$. For the reaction, $20 \mu \mathrm{L}$ of standard or samples were added to $200 \mu \mathrm{L}$ of Azure A reagent (10 mg. $\left.\mathrm{L}^{-1}\right)$. The absorbance was measured with a microplate reader (Multiskan 60, ThermoScientific) at $535 \mathrm{~nm}$ 


\section{Phenolic content}

The Folin-Ciocalteu method was used to determine the total phenolic content, as described in Le Lann et al. (2008) ${ }^{[15]}$. All extracts were prepared at different concentrations, from 1 to $0.25 \mathrm{mg} \cdot \mathrm{mL}^{-1}$. After the reaction of extracts with $\mathrm{Na}_{2} \mathrm{CO}_{3}$, distilled water and Folin Ciocalteu reagent at $70^{\circ} \mathrm{C}$, the absorbance was measured at $620 \mathrm{~nm}$ after cooling the micro plate for 10 min on ice. A phloroglucinol standard curve was drawn (0 $\left.100 \mathrm{mg} . \mathrm{L}^{-1}\right)$ and used to determine total phenolic contents for all samples.

\section{Statistical analysis}

Software R version 3.0.2 was used for the statistical analysis of biochemical data. The normality of data (Shapiro) and the homogeneity of variances (Levene) were tested. ANOVA (Analysis of variance) and HSD Tukey test were carried out if the normality and the homogeneity were validated. If not, even after data normalization (in function), non-parametric tests, i.e. Kruskal-Wallis and Wilcoxon-Mann-Whitney tests were performed. These statistical analyses allowed checking whether there was a seasonal variability (months and seasons) for each class of compounds studied. For the seasonal analysis, the following classification was made: January and February (winter); April, May and June (spring); July, August and September (summer); October, November and December (autumn).
Unscrambler X 10.3 software was used for statistical analysis of the infra-red spectroscopic data. A pretreatment of each spectrum was done with Savitzky-Golay method (smooth: 11 points). A correction of multiplicative effects was carried out with Multiplicative Scatter Correction (MSC) before the Principle Component Analysis (PCA), a method for representing individuals on a limited number of dimensions (two in this case) that allows the clustering without loss of information. PCA analysis was performed on our data set to explore link between the samples and the descriptive variables (biplot) or between the variables, as well as to do clusters between harvesting months.

\section{Result}

\section{Biochemical analysis}

Results on the biochemical composition of $S$. muticum are presented in Table 1. Biochemical analysis showed that $S$. muticum contained 20.8 - 40.5\% mineral matter, 4.9 - $13.6 \%$ neutral sugars, $1.4-3.0 \%$ uronic acids, $19.8-32.9 \%$ proteins, $6.6-10.1 \%$ sulphated groups, $2.3-4.2 \%$ phenolic compounds (Table 1). Dry matter of S. muticum ranged between 13.9 $18.3 \%$ of the fresh matter. Our results showed a strong variability of the percentage of some classes of compounds throughout the year with a variance from factor 1.5 to nearly 4 . For example, proteins and cell wall compounds varied greatly along the year compared to uronic acids, which had lower variability.

Table 1: Biochemical composition of dry powder from S. muticum determined by biochemical methods. Numbers are expressed in percent of dry matter, $\mathrm{n}=3$.

\begin{tabular}{|c|c|c|c|c|c|c|c|c|c|c|c|c|}
\hline $\begin{array}{l}\text { Sampling } \\
\text { date }\end{array}$ & $\begin{array}{l}\text { Begin- } \\
\text { ning of } \\
\text { July } 2014\end{array}$ & $\begin{array}{l}\text { Middle } \\
\text { of July } \\
2014\end{array}$ & $\begin{array}{l}\text { August } \\
2014\end{array}$ & $\begin{array}{l}\text { Septem- } \\
\text { ber } 2014\end{array}$ & $\begin{array}{l}\text { October } \\
2014\end{array}$ & $\begin{array}{l}\text { Novem- } \\
\text { ber } 2014\end{array}$ & $\begin{array}{l}\text { Decem- } \\
\text { ber } 2014\end{array}$ & $\begin{array}{l}\text { January } \\
2015\end{array}$ & $\begin{array}{l}\text { February } \\
2015\end{array}$ & $\begin{array}{l}\text { April } \\
2015\end{array}$ & $\begin{array}{l}\text { May } \\
2015\end{array}$ & $\begin{array}{l}\text { June } \\
2015\end{array}$ \\
\hline Proteins & $19.77 \pm 1.08$ & $21.15 \pm 0.37$ & $22.56 \pm 0.40$ & $23.95 \pm 2.11$ & $22.55 \pm 0.82$ & $31.67 \pm 1.06$ & $22.23 \pm 0.37$ & $23.68 \pm 1.58$ & $24.87 \pm 0.49$ & $32.98 \pm 0.93$ & $20.51 \pm 0.18$ & $20.71 \pm 0.28$ \\
\hline $\begin{array}{l}\text { Nitrogen- } \\
\text { Kjeldahl }\end{array}$ & $1.35 \pm 0.01$ & $1.29 \pm 0.04$ & $1.23 \pm 0.03$ & $1.53 \pm 0.02$ & $1.95 \pm 0.02$ & $1.62 \pm 0.01$ & $1.47 \pm 0.02$ & $2.20 \pm 0.02$ & $2.85 \pm 0.01$ & $2.45 \pm 0.03$ & $2.57 \pm 0.04$ & $1.96 \pm 0.05$ \\
\hline $\begin{array}{l}\text { Uronic } \\
\text { acids }\end{array}$ & $1.57 \pm 0.23$ & $1.38 \pm 0.03$ & $2.06 \pm 0.4$ & $2.01 \pm 0.12$ & $1.42 \pm 0.11$ & $2.11 \pm 0.16$ & $2.36 \pm 0.46$ & $3.01 \pm 0.01$ & $2.10 \pm 0.19$ & $2.35 \pm 0.05$ & $1.69 \pm 0.16$ & $2.02 \pm 0.13$ \\
\hline $\begin{array}{l}\text { Sulphated } \\
\text { groups }\end{array}$ & $6.76 \pm 0.06$ & $7.48 \pm 0.03$ & $8.25 \pm 0.04$ & $7.24 \pm 0.01$ & $6.65 \pm 0.09$ & $9.31 \pm 0.11$ & $8.61 \pm 0.44$ & $9.59 \pm 0.17$ & $9.27 \pm 0.08$ & $10.13 \pm 0.12$ & $8.89 \pm 0.11$ & $8.73 \pm 0.05$ \\
\hline $\begin{array}{l}\text { Mineral } \\
\text { matter }\end{array}$ & $36.57 \pm 0.07$ & $38.33 \pm 0.06$ & $40.12 \pm 0.39$ & $37.90 \pm 0.37$ & $40.54 \pm 0.34$ & $27.72 \pm 0.14$ & $27.11 \pm 0.04$ & $24.68 \pm 0.45$ & $26.84 \pm 0.05$ & $25.27 \pm 1.09$ & $20.80 \pm 0.26$ & $20.90 \pm 0.28$ \\
\hline $\begin{array}{l}\text { Phenolic } \\
\text { com- } \\
\text { pounds }\end{array}$ & $2.79 \pm 0.05$ & $3.39 \pm 0.17$ & $2.88 \pm 0.25$ & $3.19 \pm 0.05$ & $2.41 \pm 0.03$ & $3.81 \pm 0.14$ & $2.26 \pm 0.10$ & $2.69 \pm 0.11$ & $3.18 \pm 0.05$ & $4.21 \pm 0.24$ & $2.71 \pm 0.06$ & $2.80 \pm 0.36$ \\
\hline $\begin{array}{l}\text { Neutral } \\
\text { sugars }\end{array}$ & $5.23 \pm 0.34$ & $8.06 \pm 0.36$ & $9.42 \pm 0.51$ & $7.92 \pm 0.57$ & $4.99 \pm 0.14$ & $6.63 \pm 0.51$ & $5.82 \pm 0.13$ & $4.89 \pm 0.44$ & $5.46 \pm 0.12$ & $8.44 \pm 0.26$ & $12.67 \pm 0.46$ & $13.58 \pm 0.73$ \\
\hline
\end{tabular}

The harvest season of $S$. muticum had a significant effect on polysaccharides (uronic acids) levels (ANOVA, p < 0.05 ), as well as on sulphated compounds and nitrogen composition (Kruskal-Wallis, $\mathrm{p}<0.001$ ). Significant differences between cold (January to March) and warm (July to September) months were observed for uronic acids. Concerning polysaccharides, the composition differed significantly between seasons, except between autumn and winter, showing no variation of polysaccharides content (Tukey HSD, $\mathrm{p}<0.05$ ). Wilcoxon-Mann-Whitney test indicated a significant difference in sulphate levels between autumn and winter, summer and winter, as well as summer and spring $(\mathrm{p}<0.05)$. For nitrogen content, there was a significant difference between all seasons $(p<0.005)$ except between winter and spring (Wilcoxon, $\mathrm{p}=0.316$ ). Phenolic contents present- ed significant variation between months (ANOVA, $\mathrm{p}<0.001$ and Tukey HSD, $\mathrm{p}<0.05$ ), but if data are clustered by season, no significant difference was detected between the seasons (ANOVA, $p=0.5481$, Tukey HSD, $p>0.05$ ). For proteins, there was no significant difference between seasons (Kruskal-Wallis, $\mathrm{p}=$ 0.189), except for October and April (Wilcoxon-Mann-Whitney, $\mathrm{p}<0.05)$.

\section{Relations between biochemical composition and meteorolog- ical factors}

Correlation between the biochemical composition of $S$. muticum and environmental parameters was evaluated in order to better understand the influence of these factors on the variation of $S$. muticum biochemical composition. Relations between 
variables (meteorological and biochemical) and individuals data are represented with a PCA (Figure 1). The analysis was performed on 36 samples (three per month), using following variables (nitrogen, sulphated compounds, proteins, uronic acids, phenolic compounds content; meteorological data: air temperature, seawater temperature, sunlight, rainfall).

It is noticeable that, from June to September, the macroalga was influenced by temperature and sunlight (Figure 1). April and October data follow the axis of proteins and February, the axis of uronic acids. One should then note that data were greatly influenced by respectively proteins and uronic acids contents. Precipitations seem to influence the distribution of data obtained in May 2015.

Furthermore, biochemical composition of $S$. muticum analyzed with colorimetric method was not directly related to the meteorological factors (temperature, sunlight). Meanwhile, the rainfall was inversely related to phenolic content of $S$. muticum. Moreover, nitrogen and uronic acids were inversely related to seawater temperature. Nitrogen and uronic acids followed the same trend and protein content followed the same direction but did not overlap them (Figure 1).

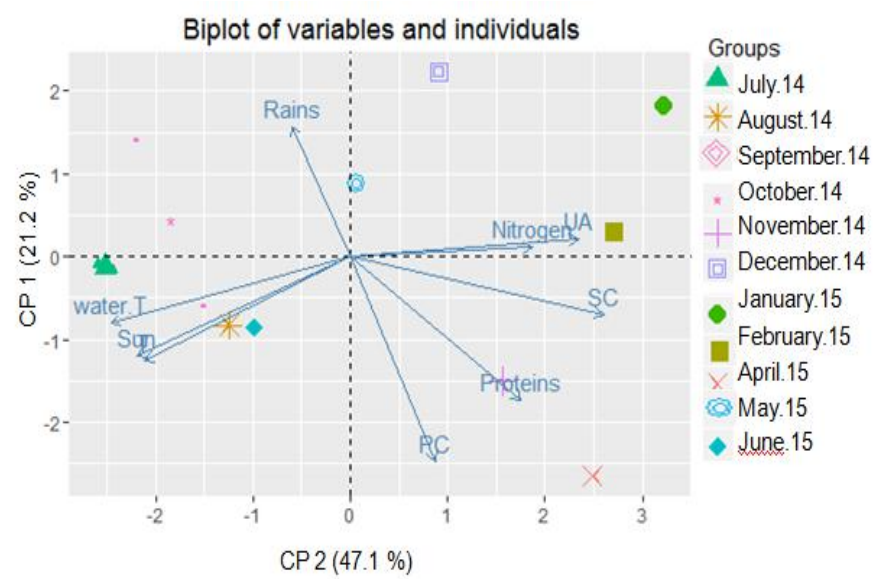

Figure 1: PCA biplot of descriptive variables and individuals corresponding to samples of Sargassum muticum collected at Piriac (France) from July 2014 to June 2015. Biochemical data: Proteins, Nitrogen, Sulphated Compounds (SC), Uronic Acids (UA), Phenolic Compounds (PC) content; meteorological data: Air temperature (T.), Temperature of seawater (water T), Sunlight (Sun), Rains. CP 1 (47.1\%) and CP 2 $(21.2 \%)$.

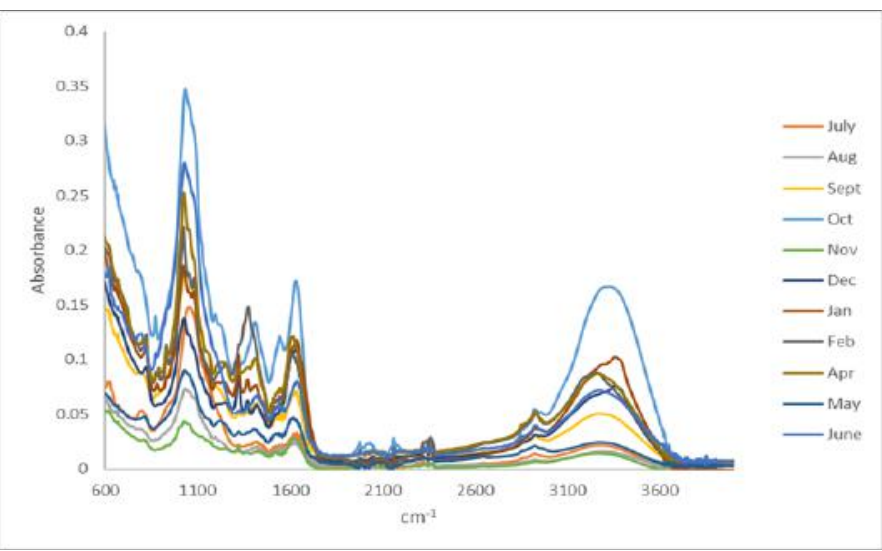

Figure 2: FTIR spectra of dry powder of $S$. muticum collected at Piriac (France) from July 2014 to June 2015, 500 - $4000 \mathrm{~cm}^{-1}, 32$ scans. Resolution: $2 \mathrm{~cm}^{-1}$.
FTIR spectra of each monthly sample are presented on Figure $2\left(500-4000 \mathrm{~cm}^{-1}\right)$. The comparison of the spectra was performed from 600 to $1800 \mathrm{~cm}^{-1}$ with a Principle Component Analysis (PCA, Figure 3). PCA showed that S. muticum biochemical composition could be differentiated into three clusters: autumn/winter (October to January); spring (April to June) and summer (July to September). The differentiation of February data can be underlined. Moreover, the spring months are grouped together whereas the summer months have a linear distribution along the principal component 1.

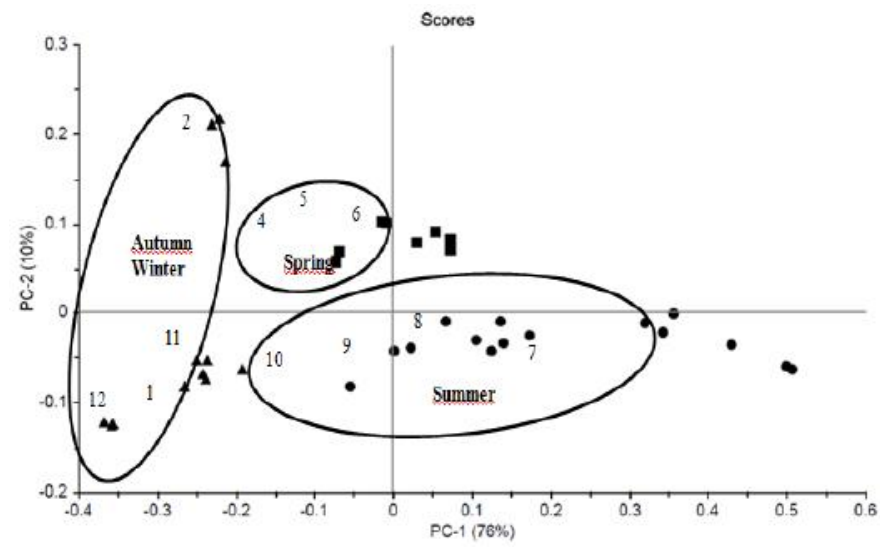

Figure 3: PCA on FTIR spectra data from freezed-dried samples of $S$. muticum collected at Piriac (France) from July 2014 to June 2015. The area $600-1800 \mathrm{~cm}^{-1}$ was selected to study all the metabolites of $S . m u$ ticum while avoiding water band $\left(3000-3600 \mathrm{~cm}^{-1}\right)$. Numbers indicate month of sampling and PC correspond to principal component.

Analysis of seasonal variation can be performed for each class of macromolecules, i.e. proteins, polysaccharides, phenolic compounds. The aim was to check characteristic absorption bands found in the literature ${ }^{[25,26]}$ and confirmed by the commercial standards can be properly used. In this present study, the results for proteins, uronic acids, polysaccharides, phenolic and sulphated compounds are illustrated on Figure 4, Figure 5 and Table 2.

Spectral data distribution of samples for proteins bands (3450 - $3600 \mathrm{~cm}^{-1}$, Amide A: N-H; $1650 \mathrm{~cm}^{-1}$, Amide I: C=O; $1560 \mathrm{~cm}^{-1}$ Amide II: N-H; $\left.1450 \mathrm{~cm}^{-1}, \mathrm{dCH}_{2}-\mathrm{CH}_{3}\right)$ are presented on Figure 4a. Three seasonal groups were distinguished (summer, winter and intermediary seasons: autumn and spring). It can be noted that the clusters were sometimes overlapped, as it was seen for September (belonging to summer group) which appeared in our analysis near winter and transition season cluster.

PCA on uronic acids characteristic bands (930 - 940 $\mathrm{cm}^{-1}, \mathrm{C}-\mathrm{O}-\mathrm{C} ; 1035$ - $1090 \mathrm{~cm}^{-1}, \mathrm{C}=\mathrm{O} ; 1395$ - $1415 \mathrm{~cm}^{-1}, \mathrm{C}-\mathrm{OH}$; $1595-1705 \mathrm{~cm}^{-1}$, aromatic core) showed three distinct seasonal groups: summer, spring and autumn/winter(Figure 4b). Uronic acids data seemed to constitute a gradient between cold months and hot months except for February data. Overall, the summer data tended to gather near the principal component 1 .

The polysaccharide data presented seasonal variation according to PCA on their characteristic FTIR bands (815 - 825 $\mathrm{cm}^{-1}$, mannuronic acid band; $875-895 \mathrm{~cm}^{-1}, \mathrm{C} 1-\mathrm{H} \beta$ mannuronic acid; $1025-1030 \mathrm{~cm}^{-1}$, characteristic polysaccharides band; $1070-1085 \mathrm{~cm}^{-1}, \mathrm{C}=\mathrm{O}$ guluronic acid band; $1320 \mathrm{~cm}^{-1}$, mannuronic acid band). Like uronic acids, three groups were distinguished (summer, spring and autumn/winter). Spring months as 
well as autumn/winter months were very close, compared to summer months. The latter had an extended distribution mainly due to July, which differed from the group in terms of composition (Figure 4c).
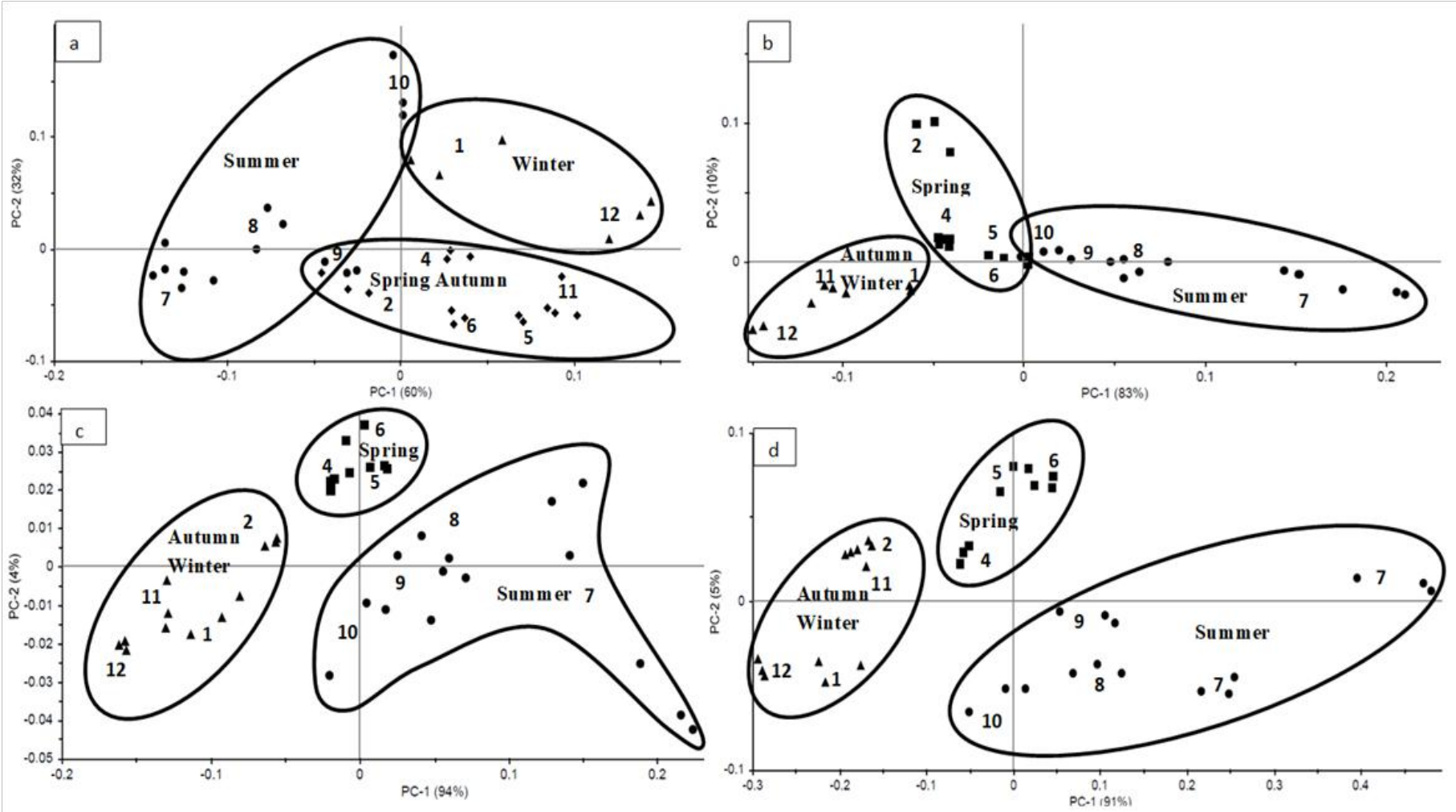

Figure 4: Spectra of dry powder of S. muticum samples collected at Piriac (July 2014 to June 2015). A PCA was carried out on FTIR characteristic bands of followed groups: proteins (A): $1440-1660 \mathrm{~cm}^{-1}$ and $3450-3600 \mathrm{~cm}^{-1}$, uronic acids (B): 930 - 940; $1035-1090 ; 1395-1415 ; 1595-1705$ $\mathrm{cm}^{-1}$, polysaccharides (C): $815-825 ; 875-895 ; 1025-1030 ; 1070-1085 ; 1320 \mathrm{~cm}^{-1}$, sulphated compounds (D): $1015-1300 \mathrm{~cm}^{-1} . \mathrm{Numbers}$ indicate month of sampling, with 1 corresponding to January.

Table 2: Synthesis of absorption bands used for the multivariate analysis carried out on each class of macromolecules. Wave numbers expressed in $\mathrm{cm}^{-1}$. Bold numbers indicate band of wave numbers taken into account in multivariate analysis. Italic numbers indicate characteristic bonds.

\begin{tabular}{|llll|}
\hline Proteins & Uronic acids & Sulphated compounds & Polysaccharides \\
\hline $1450\left(\mathrm{dCH}_{2}-\mathrm{CH}_{3}\right)$ & $932(\mathrm{C}-\mathrm{O}-\mathrm{C})$ & $1030(\mathrm{O}=\mathrm{S}=\mathrm{O})$ & 817 (mannuronic acid) \\
$1560(\mathrm{~N}-\mathrm{H})$ & $\mathbf{9 3 0}-\mathbf{9 4 0}$ & $1040-1250($ ester sulfates $)$ & $\mathbf{8 1 5}-\mathbf{8 2 5}$ \\
$1650(\mathrm{C}=\mathrm{O})$ & $1045(\mathrm{v} \cdot \mathrm{C}-\mathrm{O})$ & $1210-1280(\mathrm{~S}=\mathrm{O})$ & $890\left(\mathrm{C}_{1}-\mathrm{H} \beta\right.$ mannuronic acid $)$ \\
$\mathbf{1 4 4 0}-\mathbf{1 6 6 0}$ & $1080(\mathrm{C}-\mathrm{O})$ & $\mathbf{1 0 1 5}-\mathbf{1 3 0 0}$ & $\mathbf{8 7 5}-\mathbf{8 9 5}$ \\
& $\mathbf{1 0 3 5}-\mathbf{1 0 9 0}$ & & 1027 (polysaccharides) \\
& & & $\mathbf{1 0 2 5}-\mathbf{1 0 3 0}$ \\
& $1406(\mathrm{C}-\mathrm{OH})$ & & 1080 (guluronic acid C-O) \\
& $\mathbf{1 3 9 5}-\mathbf{1 4 1 5}$ & & $\mathbf{1 0 7 0}-\mathbf{1 0 8 5}$ \\
& & & $\mathbf{1 3 2 0}$ (mannuronic acid) \\
& $1611($ aromatic core $)$ & & \\
& $1700(\mathrm{C}-\mathrm{O})$ & & \\
& $\mathbf{1 5 9 5}-\mathbf{1 7 0 5}$ & & \\
& &
\end{tabular}

PCA on the specific absorption bands of sulphated compounds $\left(1015-1300 \mathrm{~cm}^{-1}: 1210-1280 \mathrm{~cm}^{-1}, \mathrm{~S}=\mathrm{O} ; 1030 \mathrm{~cm}^{-1}, \mathrm{O}=\mathrm{S}=\mathrm{O}\right.$; $1040-1250 \mathrm{~cm}^{-1}$, esters sulfates) allowed to differentiate three seasonal clusters (summer, spring and autumn/winter) (Figure 4d). From autumn to spring, the distribution of samples followed the principle component 2. Conversely, the first axis mainly influenced summer months.

Phenolic compounds were also studied by infra-red spectroscopy as presented on Figure 5. Four clusters could be differentiated, corresponding to each season (winter, spring, summer and autumn). The summer cluster was the most extended cluster. 


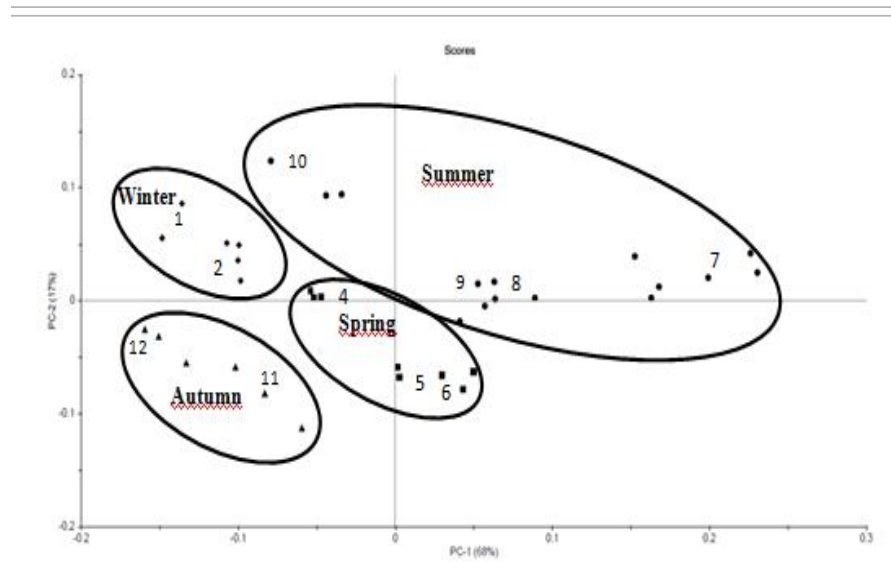

Figure 5: Spectra of S. muticum, Piriac (July 2014 to June 2015). PCA on FTIR characteristic bands of phenolic compounds: $660-675 ; 865$ - 880; 920 - 935; 1075 - 1090; 1605 - 1620; 2930 - 2945; 3200 - 3300 $\mathrm{cm}^{-1}$. Numbers indicate month of sampling.

Briefly, seasonal clusters were distributed in the same way (according to axis 1 of PCA) for uronic acids, polysaccharides and sulphated compounds.

\section{Discussion}

\section{Biochemical composition}

Table 3 summarized all the results obtained on S. muticum collected at Piriac (France) and those coming from the literature. For July 2014, the collection of $S$. muticum was performed twice; one at the beginning and one at the end of the month to evaluate the variation with the highest precision. Based on the results obtained, there were large variations in July on phenolic, sulphated compounds and polysaccharides contents.

Results between BSA protein and protein content obtained from total nitrogen analyses(using 6.25 multiplier) were not exactly the same (in mean $23.9 \%$ against $11.7 \%$ ) (Table 1 ), the differences were confirmed by PCA of variables (Figure 1). However, total nitrogen values were in coherence with those of Wernberg et al. (2001) and Hardouin et al. (2013) in Table $3^{[34,35]}$, whereas BSA data titrations were close to those of Rodriguès et al. $(2015)^{[36]}$. Kjeldahl titration is considered to be the most accurate as it is the normalized reference method (ISO 11261).

Table 3: Chemical composition of Sargassum muticum: Data and bibliographical synthesis expressed in \% of dry matter.

\begin{tabular}{|c|c|c|c|c|c|c|c|}
\hline References & $\begin{array}{l}\text { Dry matter (\% } \\
\text { fresh weight) }\end{array}$ & Proteins & $\begin{array}{l}\text { Uronic } \\
\text { acids }\end{array}$ & $\begin{array}{l}\text { Sulphated } \\
\text { groups }\end{array}$ & $\begin{array}{l}\text { Carbohy- } \\
\text { drates }\end{array}$ & $\begin{array}{l}\text { Total } \\
\text { phenolic }\end{array}$ & $\begin{array}{l}\text { Mineral } \\
\text { matter }\end{array}$ \\
\hline $\begin{array}{l}\text { Present study (July 2014- } \\
\text { June } 2015 \text { Piriac) }\end{array}$ & $12.9-18.3 \%$ & $17.6-34.6 \%$ (a) & $1.1-4.1 \%$ & $6.5-10.3 \%$ & $4.2-15.2 \%$ & $1.9-4.6 \%$ & $20.3-41.2 \%$ \\
\hline $\begin{array}{l}\text { Balboa et al., } 2013 \\
\text { (June 2010) }\end{array}$ & & $6.9 \%(b)$ & & & $26.0-46.0 \%$ & $\begin{array}{c}1.1 \% \\
\text { (EtOH extract) }\end{array}$ & $26.0 \%$ \\
\hline $\begin{array}{l}\text { Balboa et al., } 2015 \\
(2010-2011)\end{array}$ & $8.0-19.0 \%$ & $7.0-11.0 \%$ (a) & & & & & $13.2-20.5 \%$ \\
\hline $\begin{array}{l}\text { Barbarino \& Lourenço, } \\
2005 \text { (June 1998) }\end{array}$ & & $6.0 \%(b)$ & & & & & \\
\hline $\begin{array}{l}\text { Lourenço et al., } 2002 \\
\text { (June, September, 1998) }\end{array}$ & & $2.0 \%(b)$ & & & & & \\
\hline $\begin{array}{l}\text { Rodrigues et al., } 2015 \\
\text { (April 2012) }\end{array}$ & & $16.9 \%(a)$ & & & $\begin{array}{c}49.0 \% \\
\text { (substraction } \\
\text { estimation) }\end{array}$ & $0.5 \%$ & $22.9 \%$ \\
\hline Milledge et al., 2015 & & & & $1.5 \%$ & & & $29.0 \%$ \\
\hline $\begin{array}{l}\text { Jard et al., } 2013 \\
\text { (May-August 2011) }\end{array}$ & & $8.4 \%(c)$ & $13.6 \%$ & $1.4 \%$ & $\begin{array}{l}16.6 \% \\
\text { (HPLC) }\end{array}$ & $1.9 \%$ & $37.0 \%$ \\
\hline Hardouin et al., 2013 & & $\begin{array}{l}29.0 \%(d) \\
3.2 \% \text { (a) }\end{array}$ & $8.0 \%$ & $5.6 \%$ & $9.8 \%$ & $2.1 \%$ & $27.4 \%$ \\
\hline Wernberg et al., 2001 & & $1.0-4.0 \%$ (a) & & & & & \\
\hline $\begin{array}{l}\text { González-López et al., } 2012 \\
\text { (June 2010) }\end{array}$ & & $6.9 \%(\mathrm{e})$ & & & & $2.4 \%$ & $30.3 \%$ \\
\hline Gorham \& Lewey, 1984 & $8.0-17.0 \%$ & $6.9 \%(f)$ & & & $35.1 \%$ & & \\
\hline Shekhar et al., 2012 & & & & & & & $34.0-41.0 \%$ \\
\hline $\begin{array}{l}\text { Plouguerné et al., } 2006 \\
\text { (February 2003- June 2004) }\end{array}$ & & & & & & $1.1-1.9 \%$ & \\
\hline
\end{tabular}

Methods used for proteins titration : Nitrogen Total Kjeldahl (NTK) : x 6.25 (a); (Lourenço et al., 2002) x 5.38 (b); normalized method APHA x 4.92 (c); BCA titration (d); Bradford titration (e); ninhydrine reagent method (Qi et al., 2005) (f).

Uronic acids levels in this study $(1.1-4.1 \%)$, were in concordance with those measured by Jard et al. $(2013)^{[5]}$ who measured a content of $1.36 \%$ but quite far from data measured in Hardouin et al. $(2013)^{[35]}$ who obtained up to $8 \%$ of dry matter with the same method. Difference between both studies could be explained by the different period of collection or by a spatial variability.

Polysaccharides of brown algae compose up to 30 - 49\%of the cell wall (Table 3 ). Conversely, polysaccharides contents in this study were low $(4.2-15.2 \%)$. It is assumed that in most previous study, as presented on Table 3 , the polysaccharides content 
was not directly measured but obtained by calculating the difference between the total weight of the algae and the weight of all the other metabolites. Moreover, during the experiment, it was noticed a difficulty to completely hydrolyze S.muticum thallus. Thus, it would be interesting to suggest a more specific hydrolysis that could enable an extraction of all the polysaccharides constituting the cell wall, for example with $\mathrm{H}_{2} \mathrm{SO}_{4}(2 \mathrm{M})$.

Sulphated compound levels $(8.4 \%$ in mean $)$ were higher than those determined in some previous studies $(5.6 \%$, minimum value obtained $\mathrm{in}^{[35]} ; 1.4 \%{ }^{[5]}$; and $\left.1.5 \% \mathrm{in}^{[4]}\right)$. Such differences might be due to the different methods and different locations. However, this result is in accordance with fucanes percentages in algae, around $8 \%$ of dry matter ${ }^{[37]}$.

Phenolic contents and mineral matter are also in coherence with literature (Table 3 ). In this present study, variations of phenolic compounds and mineral matter are respectively comprised between $1.9-4.6 \%$ and $20.3-41.2 \%$. Balboa et al. (2013) found similar results, $1.1 \%$ for phenolic compounds and $26 \%$ for mineral matter ${ }^{[38]}$.

The following classes of macromolecules, i.e. sulphated compounds, polysaccharides, uronic acids, nitrogen compounds and proteins, presented significant variations according to the season. So meteorological factors such as seawater and/ or air temperatures, sunlight duration, precipitations seemed to influence the biochemical composition of the brown macro alga S. muticum, as confirmed by Plouguerné et al. (2006) and Le Lann et al. $(2012)^{[18,19]}$.

\section{Correlation with meteorological factor and lifecycle of the alga}

Biochemical composition (proteins, nitrogen, polysaccharides, sulfated and phenolic compounds) did not present any strong correlation with temperature (air or seawater) and sunlight. Balboa et al. (2015) experienced the same observation, obtaining a weak correlation between the biochemical composition and temperature.

An absence of correlation between temperature (air or seawater) and proteins content might be due to a light imprecision on the measured temperatures. Indeed, the meteorological data were not obtained from an in-situ measurement, but they were provided by another source (a real-time measurement from the buoy placed off the sampling location). Therefore, for further analysis, in-situ measurements of water temperature and oxygen salinity are suggested. Water current and nutrient content of seawater might also be important to measure in future studies as they were not considered in this present study.

Aside of environmental factors, it is strongly believed that the variation of $S$. muticum might be simply linked to the algal life cycle. As presented on Figure 4, there were three groups of data, i.e. winter, spring, and end of summer. The development and growth period of $S$. muticum occurs during winter and spring, and in summer, after their reproduction, the thalli begin to experience a deterioration indicated by the loss of buoyancy due to the detachment of air bladder.

\section{FTIR spectrometry}

Traces of water could be present in the dry material of S. muticum. Indeed, water (O-H bonds) mainly absorbs between 2950 and $3720 \mathrm{~cm}^{-1}$ (distilled water). Diamond crystal also causes interferences in the absorption zone between 2000 and 2200 $\mathrm{cm}^{-1}$. Therefore, we decided to study preferentially $600-1800$ $\mathrm{cm}^{-1}$ zone to exclude water and crystal absorption zones. This is the mean to avoid bias interpretation on global biochemical composition of samples $S$. muticum. Spectral resolution parameter, which was a deviation between two bands of wave number different, was set to 16 to avoid interference of signal bands, which were not representative of the algal biochemical composition.

Identification of absorption bands in infra-red spectroscopy allowed the study of each class of macromolecules independently of the season parameter (Figure 4). Moreover, as shown by the principle component analysis, this parameter had an influence on the algal composition. The principle component 1 of each group of compounds seems to be related to seasonal variation. The intensity of these variations seems to be different according to the clusters: spring months were often close together whereas summer months had a widespread distribution, meaning that the algal metabolism was more active in summer. More compounds were synthesized in summer in particular in July. Normally, in summer S. muticum stops growing, so there will be no important metabolism activity. Nevertheless, some bioactive compounds, such as phlorotannins, are synthesized. It can be an induced defense mechanism against the environmental stress such as UV radiations, predators, pathogens, etc ${ }^{[39]}$.

Sulphated compounds (PCA) could be linked to the life cycle of alga. Indeed, between winter and spring, there is a growth of the laterals, linked with the variation on the component 2. Afterwards, at the beginning of summer, reproduction takes place ${ }^{[18,19]}$ and we could observe a brutal different trend in sulphated content between June and July. Finally, content in sulphated compounds following the component 1, it can be linked to the laterals that entered in senescence at the end of the summer (Figure 4).

Phenolic compounds of $S$. muticum from this study showed a correlation (Figure 5) with seasons. These results can support that phenolic compounds in S. muticum (well known for their antioxidant activity ${ }^{[40,42]}$ serve as a protection against the exposure to sunlight ${ }^{[19]}$.

\section{Conclusion}

In this work, an innovative technique was used for the determination of S. muticum biochemical composition: Fourier Transformation Infra-Red Spectrometry. The results showed a seasonal variation of the qualitative composition of our algal model $S$. muticum using infra-red spectroscopy as well as a variation of the quantitative composition of macromolecules using classical biochemical assays. With infra-red spectrometry, the determination of characteristic compounds absorption bands (polysaccharides, proteins, uronic acids, sulphated compounds) in S. muticum was carried out. Multivariate analysis allowed the description of all the relations between the studied variables. Variations between seasons were statistically demonstrated for uronic acids, polysaccharides, sulfated compounds and proteins with biochemical analysis. These results were confirmed by FTIR seasonal clustering analysis. Seasonal variations of phenolic contents were perfectly highlighted through the analysis of FTIR spectra. For these compounds, we could suggest that this technique is more rapid and sharper than biochemical assays to show some variations but unfortunately the obtained informa- 
tion is not quantitative.

Nevertheless, data obtained from FTIR spectroscopy could contribute to a better knowledge of S.muticum and also should underline the advantage of using infra-red techniques to determine the biochemical composition of algae (rapidity, high resolution, simple use...). Fourier Transform Infra-red spectroscopy is a useful tool for the determination of variations in macro algal composition. Nevertheless, the first time that the analysis of one compound or a family of compounds is done, time is required to determine characteristic bands, as well as to compare with biochemical assays and to carry out multivariate analysis. However, when these steps are accomplished, analysis becomes simple. Among the future prospects, the quantitative evaluation of each class of macromolecules by FTIR spectroscopy thanks to regression methods using the specific absorptions bands of the studied compounds should be one of the priorities.

\section{Acknowledgements}

This work was supported by the regional research project COSELMAR (Région Pays de la Loire, IUML).

\section{Conflict of interest}

The authors declare to have no conflict of interests in this research.

\section{References}

1. Cabioc'h, J., Floc'h, J-Y., Le Toquin, A., et al. Guide des algues des mers d'Europe. Delachaux et Niestlé; 2006.

PubMed |CrossRef $\mid$ Others

2. Milledge, J., Harvey, P. Golden tides: problem or golden Opportunity? the valorisation of Sargassum from beach inundations. (2016) J Mar Sci Eng 4(3): 60.

PubMed | CrossRef | Others

3. Becker, E.W. Micro-algae as a source of protein. (2007) Biotechnol Adv 25(2): 207-210.

PubMed | CrossRef | Others

4. Milledge, J.J., Nielsen, B.V., Bailey, D. High-value products from macroalgae: the potential uses of the invasive brown seaweed, Sargassum muticum. (2016) Rev Environ Sci Biotechnol 15(1): 67-88.

PubMed | CrossRef | Others

5. Jard, G., Marfaing, H., Carrere, H., et al. French Brittany macroalgae screening: Composition and methane potential for potential alternative sources of energy and products. (2013) Bioresour Technol 144: 492-498.

PubMed | CrossRef | Others

6. Balboa, E., Gallego-Fábrega, C., Moure, A., et al. Study of the seasonal variation on proximate composition of oven-dried Sargassum muticum biomass collected in Vigo Ria, Spain. (2015) J Appl Phycol 28(3): 1943-1953.

PubMed |CrossRef | Others

7. Haug, A., Myklestad, S., Larsen, B., et al. Correlation between Chemical Structure and Physical Properties of Alginates. (1967) Acta Chemica Scandinavica 21(3): 768-778.

PubMed | CrossRef | Others

8. Rioux, L. Caractéristation structurale et évaluation de l'activité biologique de polysaccharides extraits de Saccharina longicruris. (2010) Laval, Québec.

PubMed |CrossRef| Others
9. Adhikari, U., Mateu, C.G., Chattopadhyay, K., et al. Structure and antiviral activity of sulfated fucans from Stoechospermum marginatum. (2006) Phytochemistry 67(22): 2474-2482.

PubMed | CrossRef | Others

10. Qi, H., Zhao, T., Zhang, Q., et al. Antioxidant activity of different molecular weight sulfated polysaccharides from Ulva pertusa Kjellm (Chlorophyta). (2005) J Appl Phycol 17(6): 527534.

PubMed | CrossRef | Others

11. Costa, L.S., Fidelis, G.P., Telles, C.B.S., et al. Antioxidant and anti proliferative activities of heterofucans from the seaweed Sargassum filipendula. (2011) Mar Drugs 9(6): 952-966. PubMed | CrossRef | Others

12. Deslandes, E., Pondaven, P., Auperin, T., et al. Preliminary study of the in vitro antiproliferative effect of a hydroethanolic extract from the subtropical seaweed Turbinaria ornata (Turner) J Agardh on a human non-small-cell bronchopulmonary carcinoma line (NSCLC-N6). (2000) J Appl Phycol 12(3-5): 257-262. PubMed | CrossRef | Others

13. Grauffel, V., Mabeau, S., Kloareg, B., et al. Propriétés anticoagulantes des fucanes sulfatés des algues brunes. (1985) Rapport Station Biologique de Roscoff pp: 17.

PubMed | CrossRef $\mid$ Others

14. Stiger-Pouvreau, V., Jégou, C., Cérantola, S., et al. Phlorotannins in Sargassaceae species from Brittany (France): Interesting molecules for ecophysiological and valorisation purposes. (2014) Adv Bot Res 71: 379-412.

PubMed | CrossRef | Others

15. Le Lann, K., Jegou, C., Stiger-Pouvreau, V. Effect of different conditioning treatments on total phenolic content and antioxidant activities in two Sargassacean species: comparison of the frondose Sargassum muticum (Yendo) Fensholt and the cylindrical Bifurcaria bifurcata R. Ross. (2008) Phycol Res 56(4): 238-245.

PubMed | CrossRef | Others

16. Zubia, M., Fabre, M.S., Kerjean, V., et al. Antioxidant and antitumoural activities of some Phaeophyta from Brittany coasts. (2009) Food Chem 116(3): 693-701.

PubMed | CrossRef | Others

17. Le Lann, K., Surget, G., Couteau, C., et al. Sunscreen, antioxidant, and bactericide capacities of phlorotannins from the brown macroalga Halidrys siliquosa. (2016) J Appl Phycol 28(6): 3547-3559.

PubMed | CrossRef $\mid$ Others

18. Plouguerné, E., Le Lann, K., Connan, S., et al. Spatial and seasonal variation in density, reproductive status, length and phenolic content of the invasive brown macroalga Sargassum muticum (Yendo) Fensholt along the coast of Western Brittany (France). (2006) Aquat Bot 85(4): 337-344.

PubMed | CrossRef | Others

19. Le Lann, K., Connan, S., Stiger-Pouvreau, V. Phenology, TPC and size-fractioning phenolics variability in temperate Sargassaceae (Phaeophyceae, Fucales) from Western Brittany: Native versus introduced species. (2012) Mar Environ Res 80: $1-11$.

PubMed | CrossRef | Others

20. Tanniou, A., Vandanjon, L., Goncalves, O., et al. Rapid geographical differentiation of the European spread brown macroalga Sargassum muticum using HRMAS NMR and Fourier-Transform Infrared spectroscopy. (2015) Talanta 132: 451-456. 
PubMed |CrossRef $\mid$ Others

21. Liu, F., Pang, S., Gao, S., et al. Intraspecific genetic analysis, gamete release performance, and growth of Sargassum muticum (Fucales, Phaeophyta) from China. (2013) Chinese J Oceanol Limnol 31(6): 1268-1275.

PubMed |CrossRef | Others

22. Yende, S., Harle, U., Chaugule, B. Therapeutic potential and health benefits of Sargassum species. (2014) Pharmacogn Rev 8(15): 1-7.

PubMed | CrossRef | Others

23. Yang, E., Ham, Y.M., Lee, W.J., et al. Anti-inflammatory effects of apo-9 '-fucoxanthinone from the brown alga, Sargassum muticum. (2013) Daru 21(1): 62.

PubMed | CrossRef | Others

24. Pérez-Lopez, P., Balboa, E.M., Gonzalez-Garcia, S., et al. Comparative environmental assessment of valorization strategies of the invasive macroalgae Sargassum muticum. (2014) Bioresour Technol 161: 137-148.

PubMed | CrossRef| Others

25. Pereira, L., Gheda, S.F., Ribeiro-claro, P.J.A. Analysis by Vibrational Spectroscopy of Seaweed Polysaccharides with Potential Use in Food, Pharmaceutical, and Cosmetic Industries. (2013) Int J Carbohydr Chem 2013: 1-7.

PubMed | CrossRef| Others

26. Gomez-Ordonez, E., Ruperez, P. FTIR-ATR spectroscopy as a tool for polysaccharide identification in edible brown and red seaweeds. (2011) Food Hydrocoll 25(6): 1514-1520.

PubMed | CrossRef | Others

27. Duarte, M.E., Cardoso, M. A., Noseda, M.D., et al. Structural studies on fucoidans from the brown seaweed. (2001) Carbohydr Res 333(4): 281-293.

PubMed | CrossRef | Others

28. Mecozzi, M., Pietroletti, M., Mento, R., Di. Application of FTIR spectroscopy in ecotoxicological studies supported by multivariate analysis and 2D correlation spectroscopy. (2007) Vib Spectrosc 44(2): 228-235.

PubMed |CrossRef | Others

29. Wagner, H., Liu, Z., Langner, U., et al. The use of FTIR spectroscopy to assess quantitative changes in the biochemical composition of microalgae. (2010) J Biophotonics 3(8-9): 557-566. PubMed | CrossRef | Others

30. Loraine, I. L'algue japonaise Sargassum muticum Caractéristiques et répartition. Report. (1989) Ecole Nationale Supérieur agronomique de Rennes 51.

PubMed |CrossRef | Others

31. Smith, P., Krohn, R.I., Hermanson, G.T., et al. Measurement of protein using bicinchoninic acid. (1985) Anal Biochem 150(1): 76-85.

PubMed | CrossRef | Others

32. Crooke, W.M., Simpson, W.E. Determination of ammonium in Kjeldahl digests of crops by an automated procedure. (1971) J Sci Food Agric 22(1): 9-10.

PubMed | CrossRef | Others
33. Pierre, G. Caractérisation biochimique d'exopolymères d'origine algale du bassin de Marennes-Oléron et étude des propriétés physico-chimiques de surface de micro-organismes impliquées dans leur adhésion. (2010) These. Université de La Rochelle, FRANCE.

PubMed | CrossRef | Others

34. Wernberg, T., Thomsen, M.S., Stæhr, P.A., et al. Comparative phenology of Sargassum muticum and Halidrys siliquosa (Phaeophyceae: Fucales) in Limfjorden, Denmark. (2001) Bot Mar 44(1): 31-39.

PubMed | CrossRef | Others

35. Hardouin, K., Burlot, A.S., Umami, A., et al. Biochemical and antiviral activities of enzymatic hydrolysates from different invasive French seaweeds. (2013) J Appl Phycol 26(2): 1029 1042.

PubMed | CrossRef | Others

36. Rodrigues, D., Sousa, S., Silva, A., et al. Impact of enzymeand ultrasound-assisted extraction methods on biological properties of red, brown, and green seaweeds from the Central West Coast of Portugal. (2015) J Agric Food Chem 63(12): 31773188.

PubMed | CrossRef | Others

37. Gorham, J., Lewey, S.A. Seasonal changes in the chemical composition of Sargassum muticum. (1984) Mar Biol 80(1): 103-107.

PubMed | CrossRef $\mid$ Others

38. Balboa, E., Rivas, S., Moure, A., et al. Simultaneous Extraction and Depolymerization of Fucoidan from Sargassum muticum in Aqueous Media. (2013) Mar Drugs 11(11): 4612-4627. PubMed | CrossRef | Others

39. Amsler, C. Algal chemical ecology. (2008) Springer 313. PubMed | CrossRef | Others

40. Puspita, M., Déniel, M., Widowati, I., et al. Total phenolic content and biological activities of enzymatic extracts from Sargassum muticum (Yendo) Fensholt. (2017) J Appl Phycol $1-17$.

PubMed | CrossRef $\mid$ Others

41. Anaëlle, T., Serrano Leon, E., Laurent, V., et al. Green improved processes to extract bioactive phenolic compounds from brown macroalgae using Sargassum muticum as model. (2013) Talanta 104: 44-52.

PubMed | CrossRef | Others

42. Tanniou, A., Vandanjon, L., Incera, M., et al. Assessment of the spatial variability of phenolic contents and associated bioactivities in the invasive alga Sargassum muticum sampled along its European range from Norway to Portugal. (2013) J Appl Phycol 26(2): 1215-1230.

PubMed | CrossRef | Others
Ommega Online Publisher

Journal of Analytical, Bioanalytical and Separation Techniques

Short Title : J Anal Bioanal Sep Tech
E-mail: analyticaltech@ommegaonline.com website: www.ommegaonline.org 